
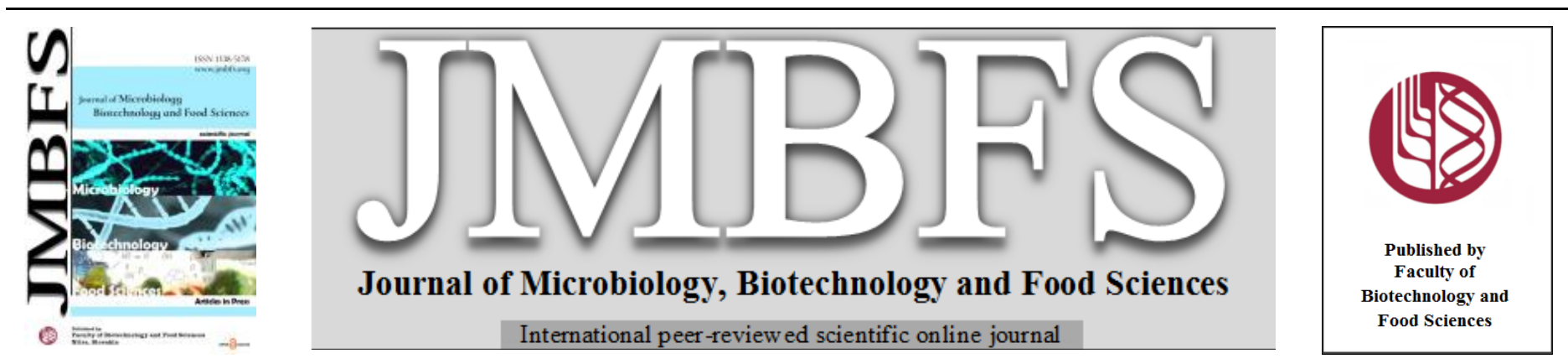

\title{
BENEFICIALL EFFECT OF THE EUROPEAN RASPBERRY (RUBUS IADEUS) EXTRACT ON THE ACTIVITY AND OXIDATIVE PROFILE OF BOVINE SPERMATOZOA
}

\author{
Ján Kováč ${ }^{*}$, Július Arvay ${ }^{2}$, Natália Konečná ${ }^{1}$, Michal Ďuračka ${ }^{1}$, Eva Tvrdá \\ Address(es): Ing. Ján Kováč, \\ ${ }^{1}$ Slovak University of Agriculture in Nitra, Faculty of Biotechnology and Food Sciences, Department of Animal Physiology, Tr. A. Hlinku 2, 94976 Nitra, Slovak \\ Republic. \\ ${ }^{2}$ Slovak University of Agriculture in Nitra, Faculty of Biotechnology and Food Sciences, Department of Chemistry, Tr. A. Hlinku 2, 94976 Nitra, Slovak Republic.
}

*Corresponding author: jan.johnny.kovac@gmail.com

https://doi.org/10.15414/jmbfs.2353

\section{ARTICLE INFO}

Received 18. 11. 2019

Revised 15. 6. 2021

Accepted 29. 6. 2021

Published 1. 12. 2021

Regular article

OPEN $\partial_{\text {ACCESS }}$

\begin{abstract}
Berries belong to the best dietary sources of bioactive compounds. These fruits contains bioactive compounds such as antioxidants (phenolic compounds and fruit colorants), vitamins (ascorbic acids) and minerals. This study aimed to estimate the effect of three concentrations $(75 \mu \mathrm{g} / \mathrm{mL}, 150 \mu \mathrm{g} / \mathrm{mL}$ and $300 \mu \mathrm{g} / \mathrm{mL}$ ) of the European raspberry (Rubus iadeus) on the selected quality parameters of bovine spermatozoa after $0 \mathrm{~h}, 2 \mathrm{~h}$, and $24 \mathrm{~h}$ of in vitro culture. Sperm motility was evaluated using the Computer-assisted sperm analysis (CASA) system. The mitochondrial activity was detected by the metabolic (MTT) assay. The determination of ROS (Reactive Oxygen Species) quantity was observed through the luminol method. The protein and lipid oxidation were evaluated using spectrophotometric assays. The experiment showed that the highest applied concentration of European raspberry extract at $2 \mathrm{~h}(\mathrm{p}<0.05)$ and all concentration after $24 \mathrm{~h}(\mathrm{p}<0.05 ; \mathrm{p}<0.001)$ exhibited motility-promoting effects. We observed the highest increase of mitochondrial activity using 300 $\mu \mathrm{g} / \mathrm{mL}$ by $2 \mathrm{~h}(\mathrm{p}<0.05)$ and using $150 \mu \mathrm{g} / \mathrm{mL}(\mathrm{p}<0.05)$ and $300 \mu \mathrm{g} / \mathrm{mL}(\mathrm{p}<0.01)$ after $24 \mathrm{~h}$. Exposure to this extract led to decreasing levels of ROS generation at $2 \mathrm{~h}$ of incubation $(\mathrm{p}<0.05)$ with the highest dose as well as after $24 \mathrm{~h}$ using $150 \mu \mathrm{g} / \mathrm{mL}(\mathrm{p}<0.01)$ and 300 $\mu \mathrm{g} / \mathrm{mL}(\mathrm{p}<0.001)$ applied doses. The protein oxidation levels showed decreasing rates at $2 \mathrm{~h}(\mathrm{p}<0.05 ; 300 \mu \mathrm{g} / \mathrm{mL})$ and at time of $24 \mathrm{~h}$ $(\mathrm{p}<0.01 ; 150 \mu \mathrm{g} / \mathrm{mL}$ and $\mathrm{p}<0.001 ; 300 \mu \mathrm{g} / \mathrm{mL})$. All selected raspberry concentration prevented oxidative degeneration of lipids during $2 \mathrm{~h}(\mathrm{p}<0.05)$ and after $24 \mathrm{~h}(\mathrm{p}<0.05 ; \mathrm{p}<0.001)$. Our results indicate, that European raspberry extract has beneficial effect on the measured parameters of the bovine spermatozoa during in vitro incubation but depending on time and applied dose.
\end{abstract}

\section{INTRODUCTION}

Raspberry plant belongs to the Rosaceae family. Rubus idaeus is a small fruit which grows on different places in the world (Gordon and Woodford, 2000). Raspberries as the most popular berry fruit in Europe is produced in Poland, as well as in Serbia and Spain (Ponder and Hallmann, 2019).

The increased consumption of fruits and vegetables for their antioxidan phytochemical contents is recommended by dietary guidelines to prevent chronic diseases. Secondary metabolites produced by the plant are characterized by a relatively strong biological activity (Bobinaité et al., 2012). Fruits, especially berries contain sources of natural antioxidants and are an excellent component of a healthy diet (Baby et al., 2017). The major health benefits of berry fruits are referred to the phenolic compounds, like flavonoids, phenolic acids and tannins (Baranowska et al., 2014). Polyphenolic compounds such as anthocyanins and ellagitannins are the most common antioxidant phytochemicals present in raspberries (Rao and Snyder, 2010). The anthocyanins as a natural organic compound are known for their preventive effects against diseases, such as tumor, senile and cardiovascular diseases. Anthocyanins can protect cells and body from oxidation by scavenging free radicals (Teng $\boldsymbol{e t}$ al., 2017). Biological activities and higher anthocyanin content of the raspberry indicate that their consumption would be useful for health, and that they could be used during production of functional foods with effective dose of anthocyanins (Bowen-Forbes et al., 2010). Phenolic compounds composition, concentration and related antioxidant activity in berries depend on the maturity of fruit, agro - environmental conditions and post - harvest technologies (Veljković et al., 2019).

Bioactive components in berries exhibit antimicrobial, anticancer, antidiabetic, anti-inflammatory, antioxidant and cardioprotective properties (Baby et al., 2017; Veljković et al., 2019; Noratto et al. 2017). The fruit of Rubus idaeus is the most common herbal drug in folk medicine, but the shoots of this plant can be also used as a treatment to cold, fever or flu - like infections (Baranowska $\boldsymbol{e t}$ al., 2014). Raspberry leaves are also used for tea, and in folk medicine has been used to treat wounds, colic pain, diarrhoea and as a uterine relaxant for centuries (Vera et al., 2002).

Despite its importance, the effect of European raspberry on the male reproductive system is still unclear. The aim of this in vitro study was to evaulate the chemical composition and the effects of raspberry on the male reproductive cells.

\section{MATERIAL AND METHODS}

\section{Plant material collection and processing}

Raspberry fruits were collected at the Botanical Garden of the Slovak University of Agriculture in Nitra, Slovakia at the end of July 2016. After the drying process, the fruits were crushed, weighed and soaked in ethanol (96\%, Centralchem, Bratislava, Slovakia) during 14 days at room temperature in the dark in order to avoid the degradation of active biomolecules. The ethanolic extracts were subjected to evaporation under reduced pressure at $40{ }^{\circ} \mathrm{C}$ (Stuart RE300DB rotary evaporator, Bibby Scientific Limited, UK, and vacuum pump KNF N838.1.2KT.45.18, KNF, Germany) to eliminate any residual ethanol. Crude extracts were dissolved in DMSO (Dimethyl sulfoxide; Sigma-Aldrich, St. Louis, USA) and adjusted to $1000 \mathrm{mg} / \mathrm{mL}$ as stock solution.

For the following chemical analysis, the fruits were freeze dried and milled. Methanol extracts were produced by adding $25 \mathrm{~mL} 80 \%$ aqueous methano (HPLC grade; Sigma-Aldrich) to $1 \mathrm{~g}$ of each sample. The mixtures were shaken at room temperature for $8 \mathrm{~h}$ on a horizontal shaker $(250 \mathrm{rpm})$. The samples were then filtered through filter paper ( $84 \mathrm{~g} / \mathrm{m} 2$; Munktell, Germany) and kept at $5{ }^{\circ} \mathrm{C}$ for further analysis.

\section{HPLC-DAD analysis}

Standards, methanol (HPLC grade), acetonitrile (gradient HPLC grade) and phosphoric acid (ACS grade) were purchased from Sigma-Aldrich. Double 
deionized water $(\mathrm{ddH} 2 \mathrm{O})$ was adjusted $\left(0.054 \mathrm{mS} / \mathrm{cm}^{1}\right)$ in a Simplicity 185 purification system (Millipore SAS, Molsheim, France). Standard solutions were prepared by dissolving $0.5 \mathrm{mg}$ each of them with methanol in $10 \mathrm{ml}$. Following homogenization the lyophilized samples $(2 \mathrm{~g})$ were extracted with $20 \mathrm{ml}$ of $80 \%$ methanol at laboratory temperature for $8 \mathrm{~h}$ by horizontal shaker (Unimax 2010 Heidolph Instrument $\mathrm{GmbH}$, Germany). The extract was filtered through munktell no 390 paper (Munktell \& Filtrac, Germany) and stored in closed $20 \mathrm{ml}$ vial tubes. Prior to injection the standard solutions and extracts were filtered through the q-max syringe filter $(0.22 \mathrm{~mm}, 25 \mathrm{~mm}$; Frisenette Aps, Knebel, Denmark) (Bajčan et al., 2016).

For the determination of the chemical composition of the European raspberry extract the agilent 1260 infinity high performance liquid chromatograph (Agilent Technologies, Waldbronn, Germany) was used with quaternary solvent manager coupled with degasser (G1311B), sample manager (G1329B), column manager (G1316A) and dad detector (G1315C). All HPLC analyses were performed on a Purosphere reverse phase C18 column (4 mm x $250 \mathrm{~mm}$ x $5 \mathrm{~mm}$ ) (Merck, KGaA Darmstadt, Germany). The mobile phase consisted of acetonitrile (gradient) (A) and $0.1 \%$ phosphoric acid in ddh2o (B). The gradient elution was as follows: $0-1$ min isocratic elution (20\% A and $80 \% \mathrm{~B}), 1-5$ min linear gradient elution (25\% A and $75 \% \mathrm{~B}), 5-15 \mathrm{~min}(30 \% \mathrm{~A}$ and $70 \% \mathrm{~B})$ and $20-25 \min (40 \% \mathrm{~A}$ and $60 \% \mathrm{~B})$. The initial flow rate was $1 \mathrm{ml} / \mathrm{min} 1$ and the injection volume was $1 \mathrm{ml}$. Column oven temperature was set up to $30{ }^{\circ} \mathrm{C}$ and the samples were kept at $4{ }^{\circ} \mathrm{C}$ in the sample manager. The data were obtained and processed using the agilent Openlab ChemStation software for LC 3D Systems (Luksic et al., 2016).

\section{Semen sample collection and processing}

Ejaculates $(\mathrm{n}=20)$ were collected from four adult Holstein Friesian breeding bulls (Slovak Biological Services, Nitra, Slovak Republic). Semen samples were obtained regularly (once a week for five consecutive weeks) from each anima using an artificial vagina. Right after the collection, semen concetration and motility were estimated by phase-contrast microscopy $(200 \mathrm{x})$. Samples with required quality (min. $70 \%$ motility and concetration of $1 \times 10^{9} \mathrm{sperm} / \mathrm{mL}$ ) were chosen for further experiments. Institutional nad national guidelines for the care and use of animals were followed, and all experimental processes were confirmed by the State Veterinary and Food Institute of Slovak Republic (no. 3398/11 221/3) and Ethics Committee.

Ejaculates were diluted in PBS (Dulbecco's Phosphate Buffer Saline without calcium chloride and magnesium chloride; Sigma Aldrich) containing differen concentrations of the European raspberry extract $(300 ; 150 ; 75 \mu \mathrm{g} / \mathrm{mL})$ using a dilution ratio of 1:40. Each semen samples were cultured at laboratory temperature $\left(22-25^{\circ} \mathrm{C}\right)$. After culture periods of $0,2,24 \mathrm{~h}$, spermatozoa motility, mitochondrial activity reactive oxygen species (ROS) production, protein and lipid peroxidation were evaluated in each group.

\section{Spermatozoa motility analysis}

Sperm motion parameters were measured using the computer-aided sperm analysis CASA; Version 14.0 TOX IVOS II.; Hamilton-Thorne Biosciences, Beverly, MA, USA). The system was set up as follow: freame rate $-60 \mathrm{~Hz}$ minimum contrast -20 ; static head size $-0.25-5.00$; static head intensity -0.40 - 2.00; static elongation $-20-100$; default cell size - 4 pixels; default cell intensity -40 . Ten microliters of each semen sample were placed into the Makler counting chamber (depth $10 \mu \mathrm{m}, 37^{\circ} \mathrm{C}$; Sefi Medical Instruments, Haifa, Israel) and spermatozoa motility (MOT; percentage of motile spermatozoa; motility $>5$ $\mathrm{m} / \mathrm{s} ; \%$ ) was assessed immediately. Ten fields of the microscope were subjected to each analysis to contain at least 300 cells (Tvrdá et al., 2018).

\section{Mitochondrial activity (MTT test)}

Mitochondrial activity of the spermatozoa was assessed using the colorimetric metabolic activity (MTT) test. This process is based on the transformation of a yellow tetrazolium salt $(3-(4,5-$ dimetylthiazol $-2-$ yl $)-2,5-$ diphenyltetrazolium bromide; MTT) to blue formazan particles by mitochondrial succinate dehydrogenase of intact mitochondria within living cells. The tetrazolium salt (Sigma - Aldrich) was dissolved in PBS (Dulbecco's Phopshate Buffer Saline without calcium chloride and magnesium chloride; Sigma Aldrich) at $5 \mathrm{mg} / \mathrm{mL}$. Each semen suspension was mixed with $10 \mu \mathrm{L}$ of the tetrazolium solution. Following 2 hours of incubation (shaker, $37{ }^{\circ} \mathrm{C}, 95 \%$ air atmosphere, $5 \% \mathrm{CO}_{2}$ ), the formazan crystals were dissolved in $80 \mu \mathrm{L}$ of acidified $(0.08 \mathrm{~mol} / \mathrm{L} \mathrm{HCl}$; Centralchem) isopropanol (Centralchem). Optical density was established at a wavelength of $570 \mathrm{~nm}$ against $620 \mathrm{~nm}$ as reference using a Multiskan FC microplate photometer (Thermo Fisher Scientific Inc., Waltham, MA, USA). Data are expressed as percentage of the control set to 100 \% (Kňažická et al., 2012).

\section{Reactive Oxygen Species (ROS) generation}

ROS production was analysed in all groups by the chemiluminescence assay using luminol (5 - amino - 2,3 - dihydro - 1,4 phthalazinedione; Sigma -
Aldrich) as the probe (Kashou et al., 2013). The blank contained $400 \mu \mathrm{L}$ of PBS, negative control consisted of $400 \mu \mathrm{L}$ of PBS, luminol $(10 \mu \mathrm{L}, 5 \mathrm{mM})$ and positive control was added by extra $25 \mu \mathrm{L}$ hydrogen peroxide $(30 \% ; 8.8 \mathrm{M}$ Sigma - Aldrich). The experimental samples and tested control contained $400 \mu \mathrm{L}$ of luminol and sample. Chemiluminescence was assessed by Glomax Multi Combined Spectro - Fluoro Luminometer (Promega Corporation, Madison, WI, USA) on 48 - well plates in 15 cycles of $1 \mathrm{~min}$. The results are expressed as relative light units (RLU)/s/10 6 spermatozoa.

\section{Protein oxidation}

The protein carbonyl content was quantificated using the standard 2,4 dinitrophenylhydrazine (DNPH) method. One $\mathrm{mL}$ of the pre - treated sample was mixed with one $\mathrm{mL}$ DNPH $(10 \mathrm{nM}$ in $2 \mathrm{~N} \mathrm{HCl}$; Sigma Aldrich) and incubated at $37{ }^{\circ} \mathrm{C}$ in the dark place for one hour. After $1 \mathrm{~mL}$ trichloro acetic acid $(20 \% \mathrm{w} / \mathrm{v}$; Sigma Aldrich) addition, the compound was incubated at $4{ }^{\circ} \mathrm{C}$ for $10 \mathrm{~min}$ and afterwards centrifuged at $11828 \times \mathrm{g}$ for $15 \mathrm{~min}$. The supernatant was removed without interfering the pellet which was subsequently washed three times with one $\mathrm{mL}$ ethanol/ethyl acetate $(1 / 1 ; \mathrm{v} / \mathrm{v})$ to discard any free DNPH reagent. Lastly, the pellet was resuspended in $1 \mathrm{~mL} 6 \mathrm{M}$ guanidine - $\mathrm{HCl}$ (Sigma - Aldrich) before absorbance measurement at $360 \mathrm{~nm}$, using $6 \mathrm{M}$ guanidine $-\mathrm{HCl}$ as a blank solution. The molar absobtion coeficient of $22000 \mathrm{M} / \mathrm{cm}$ was used to determine the concetration of protein carbonyls. The measurements are formulated as $\mathrm{nmol} / \mathrm{mg}$ protein (Weber et al., 2015)

\section{Lipid peroxidation}

The extent of lipid peroxidation which was formulated as malondialdehyde (MDA) concetration was determined with the help of the TBARS assay, modified for a 96 - well plate and ELISA reader. The final product generated by the reaction of MDA and thiobarbituric acid (Sigma - Aldrich) under high temperature $\left(90-100^{\circ} \mathrm{C}\right)$ and acidic conditions was measured at $530-540 \mathrm{~nm}$ (Tvrdá et al., 2016). MDA is expressed as $\mu \mathrm{mol} / \mathrm{g}$ protein.

\section{Protein quantification}

The amount of protein was evaluated using the DiaSys Total Protein (DiaSys, Holzheim, Germany) commercial kit and the Randox RX Monza clinical chemistry analyzer (Randox Laboratories, Crumlin, Great Britain). The measurement is based on the Biuret reaction in which protein is detected using a mixture of sodium hydroxide solutions and copper sulphate to form a viole blue colour complex if the protein was detected. The intesity of the colour is directly proportional to the concetration of the protein when assessed at $540 \mathrm{~nm}$

\section{Statistical analysis}

The obtained data were statisticaly analysed using the GraphPad Prism program (version 3.02 for Windows; GraphPad Software, La Jolla, CA, USA, http://www.graphpad.com). Descriptive statistical characteristics (mean, standard error) were evaluated at first. One - way Anova was used for specific statistical evaluations. Dunnett's test was applied as a follow - test to ANOVA, based on a comparisonn of every mean to a control mean, and computing a confidence interval for the difference between the two means. The level of significance was set at $* * * \mathrm{P}<0.001, * *-\mathrm{P}<0.01, *-\mathrm{P}<0.05$.

\section{RESULTS AND DISCUSSION}

For the identification and quantification of the main chemical compounds found in the European raspberry extract the high preformance liquid chromatography was used. External standard method was used for quantitative determination and the identified compounds with their concentration are showed in Table 1. The major detected compounds found in the extract were myricetin $1200.66 \mathrm{mg} / \mathrm{kg}$ and cynarozid $1176.48 \mathrm{mg} / \mathrm{kg}$. From the analyzed phenolic acids, chlorogenic acid, neochlorogenic acid, caffeic acid, trans - caffeic acid, elagic acid, trans sinapinic acid, trans - ferulic acid, rosmarinic acid and trans - coumaric acid were quantified with the first being the most abundant $(621.08 \mathrm{mg} / \mathrm{kg})$. Eight flavonoid glycosides, myricetin, cynarosid, resveratrol, quercetin, kaempferol, vitexin, rutin, apigenin were found in the European raspberry extract (Table 1). 
Table 1 Major chemical compounds identified and quantified $[\mathrm{mg} / \mathrm{kg}]$ in the Rubus iadeus extract

European raspberry extract

\begin{tabular}{lc}
\hline Cynarosid & 1176.48 \\
Rutin & 10.88 \\
Apigenin & 5.55 \\
Kaempferol & 18.97 \\
Vitexin & 9.15 \\
Quercetin & 35.44 \\
Myricetin & 1200.66 \\
Resveratrol & 55.33 \\
Chlorogenic acid & 621.08 \\
Neochlorogenic acid & 520.43 \\
Trans - Coumaric acid & 5.19 \\
Trans - Caffeic acid & 87.53 \\
Trans - Sinapinic acid & 26.55 \\
Trans Ferulic acid & 17.27 \\
Rosmarinic acid & 8.85 \\
Elagic acid & 35.34 \\
Caffeic acid & 88.89 \\
\hline
\end{tabular}

The next part of our study was focused on the in vitro effects of Rubus iadeus on five quality parameters of bovine sperm. All assessments we performed at 0,2 , 24 hours using working solutions with $300,150,75 \mu \mathrm{g} / \mathrm{mL}$ plant extract.

The first measured parameter was the sperm motility evaluated by CASA system. The $150 \mu \mathrm{g} / \mathrm{mL}$ addition of the raspberry extract exhibited positive effect during the second hour of the analysis. The highest concetration $(300 \mu \mathrm{g} / \mathrm{mL})$ significantly increased $(\mathrm{P}<0.05)$ the sperm motion when compared to the control group. Following $24 \mathrm{~h}$ the lowest and the middle raspberry extract doses showed statistically significant $(\mathrm{P}<0.05)$ increased motility of bovine spermatozoa as well as the highest concetration showed $(\mathrm{P}<0.001)$ (Figure 1).
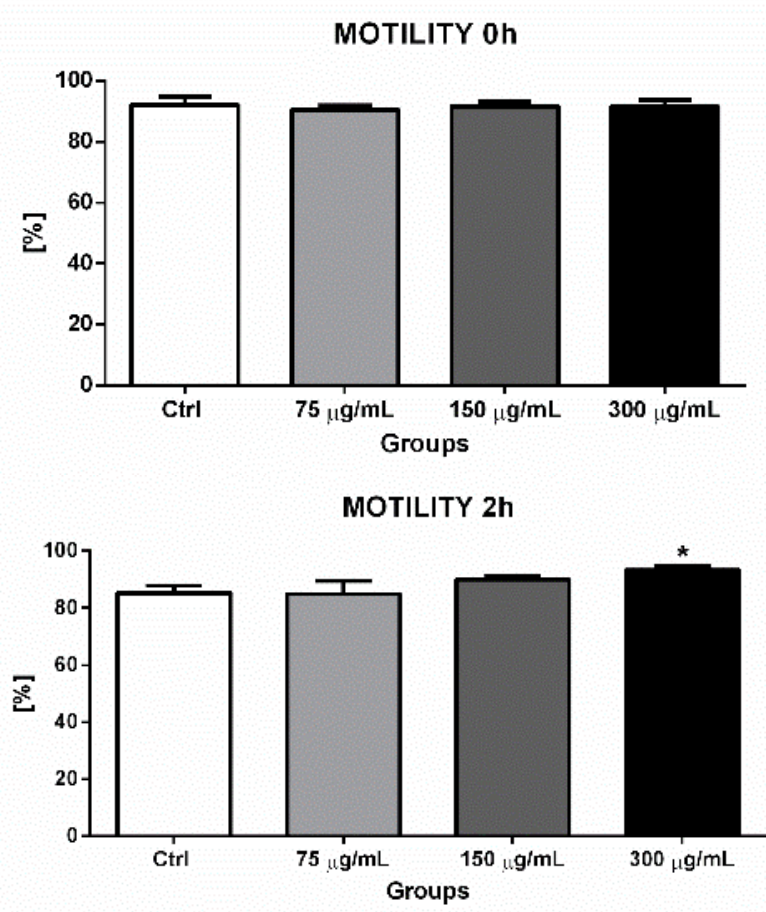

MOTILITY 24h

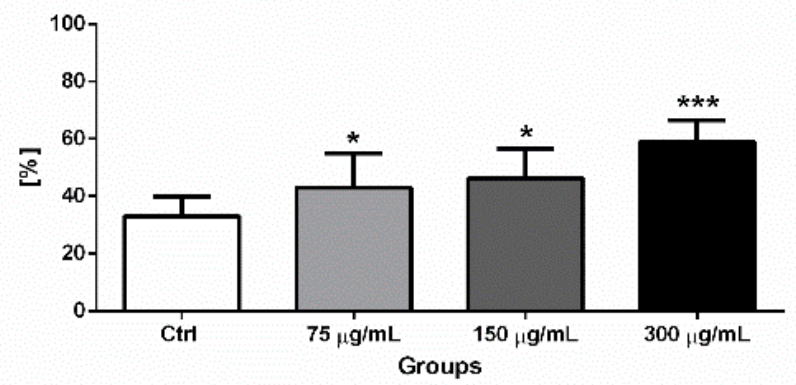

Figure 1 The effect of various concentrations of the Euroean raspberry extract on the motility of bovine spermatozoa at $0 \mathrm{~h}, 2 \mathrm{~h}$ and $24 \mathrm{~h}$. Each bar represents mean $( \pm \mathrm{SEM})$. The level of significance was set at $* \mathrm{P}<0.05$; *** $\mathrm{P}<0.001$.
Mitochondria supply the sperm cells with fuel they need to support important functions. Mitochondria provide energy for the sperm movement, so the activity of mitochondria is closely related to the motility. Therefore, we decided to analyze the effect of European raspberry extract on the mitochodria viability. Figure 2 shows the results of MTT test. At the beginning of the experiment, all concetration of the extract showed an immediate positive effect on sperm viability, but with no statistically significant difference. We observed a significant increase $(\mathrm{P}<0.05)$ of the mitochondrial viability following the highest dose of extract $(300 \mu \mathrm{g} / \mathrm{mL})$ at 2 hours. After $24 \mathrm{~h}$ of incubation wiht European raspberry extract, the middle and highest concetration $(150 ; 300 \mu \mathrm{g} / \mathrm{mL})$ significantly increased the mitochondrial viability $(\mathrm{P}<0.01 ; \mathrm{P}<0.001)$. We can say, that sperm vitality can be positively affected by European raspberry extract (Figure 2).

MITOCHONDRIAL ACTIVITY oh

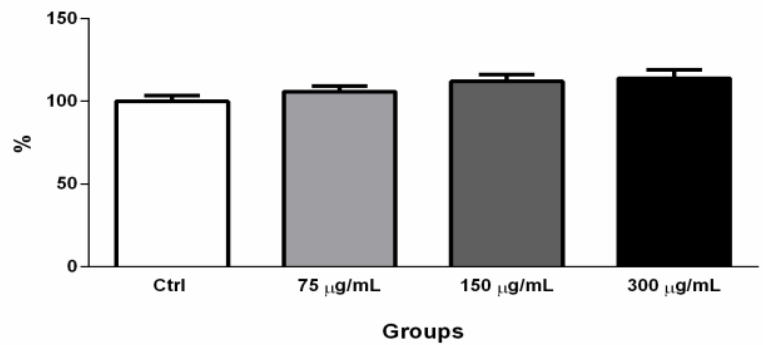

MITOCHONDRIAL ACTIVITY $2 \mathrm{~h}$

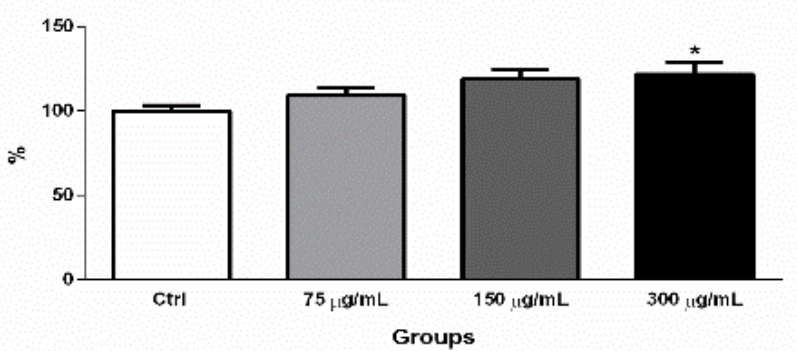

MITOCHONDRIAL ACTIVITY 24h

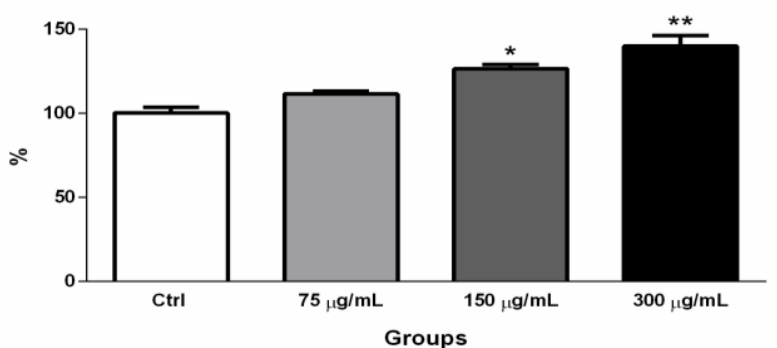

Figure 2 The effect of various concentrations of the Euroean raspberry extract on the viability of bovine spermatozoa at $0 \mathrm{~h}, 2 \mathrm{~h}$ and $24 \mathrm{~h}$. Each bar represents mean $( \pm$ SEM) optical density as the percentage of controls, which symbolize $100 \%$. The level of significance was set at $* \mathrm{P}<0.05 ; * * \mathrm{P}<0.01$.

ROS quantification was performed as high ROS production can negatively influence the plasma membrane of the sperm followed by the functional integrity of the cell. Motility and vitality can be reduced by increasing ROS levels. First measurements at $0 \mathrm{~h}$ were without any significant change. Administration of the European raspberry extract at the highest added dose $(300 \mu \mathrm{g} / \mathrm{mL})$ significantly reduced $(\mathrm{P}<0.05)$ the ROS overgeneration by male reproductive cells after $2 \mathrm{~h}$ as well as the reduction of ROS levels was significant after $24 \mathrm{~h}$ at the middle (150 $\mu \mathrm{g} / \mathrm{mL} ; \mathrm{P}<0.01)$ and by the highest European raspberry extract administration $(300 \mu \mathrm{g} / \mathrm{mL} ; \mathrm{P}<0.001)$. Therefore, we suppose that the European raspberry extract may have positive effect by reduction of reactive oxygen species production by sperm cells (Figure 3 ). 
ROS PRODUCTION Oh

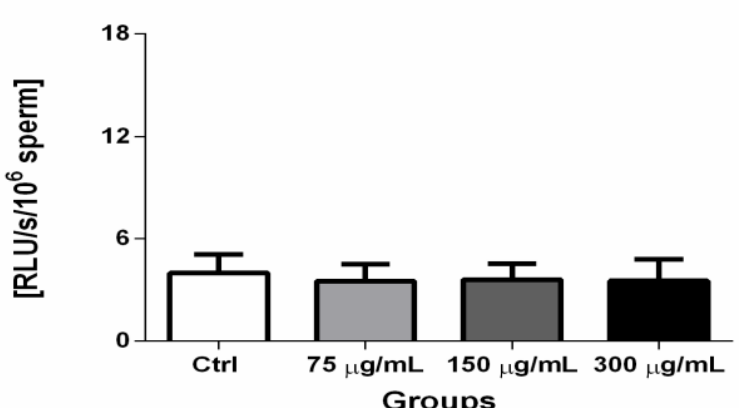

ROS PRODUCTION 2h

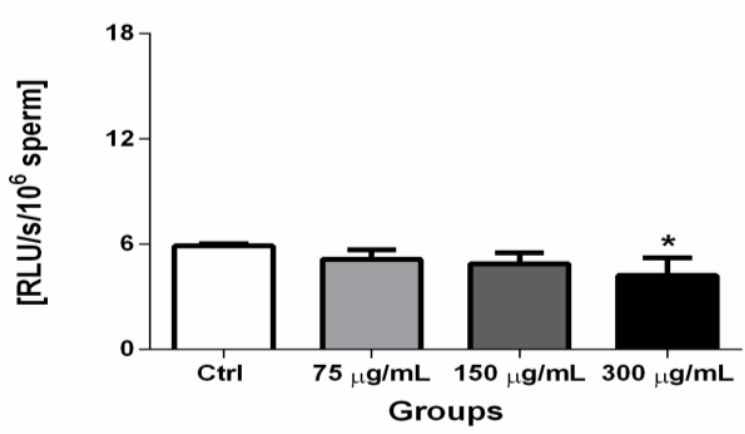

ROS PRODUCTION 24h

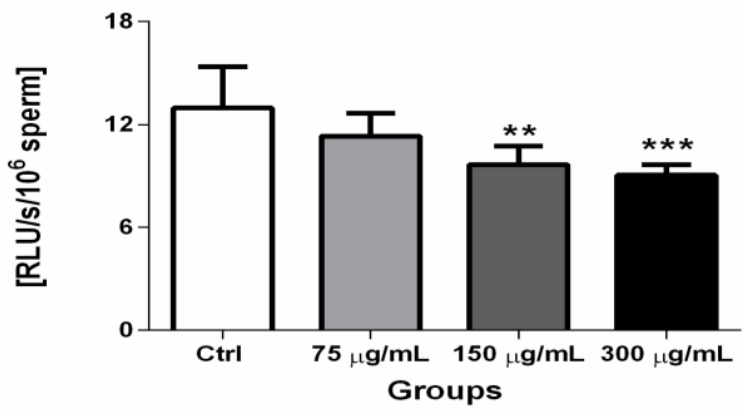

Figure 3 The effect of various concentrations of the Euroean raspberry extract on the ROS production by bovine spermatozoa at $0 \mathrm{~h}, 2 \mathrm{~h}$ and $24 \mathrm{~h}$. Each bar represents mean $( \pm \mathrm{SEM})$. The level of significance was set at $* \mathrm{P}<0.05$; $* * \mathrm{P}<$ $0.01, * * * \mathrm{P}<0.001$

Oxidation can influence the conformation or activity of proteins in male reproductive cells. Therefore, we decided to analyze the effect of the European raspberry extract on the protein modifications. Initially, no significant differences were observed. After $2 \mathrm{~h}$, the results indicated a significant difference $(\mathrm{P}<0.05)$ following the highest dose $(300 \mu \mathrm{g} / \mathrm{mL})$. Following $24 \mathrm{~h}$, we experienced that al groups exhibited decreasing levels but only groups treated with $150 \mu \mathrm{g} / \mathrm{mL}$ showed singnificant decreasing levels $(\mathrm{P}<0.01)$ of protein oxidation after European raspberry extract additon, as well as by the highest added dose of this extract $(300 \mu \mathrm{g} / \mathrm{mL} ; \mathrm{P}<0.001)$. These facts may suggest, that sperm cells can be treated by this extract to decrease protein oxidation (Figure 4).
PROTEIN OXIDATION Oh

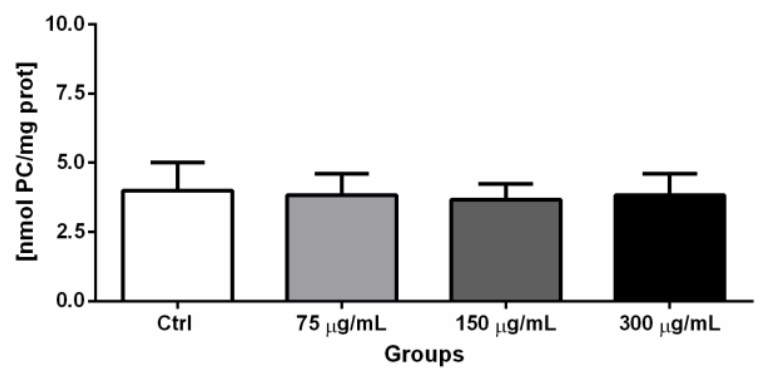

PROTEIN OXIDATION $2 h$

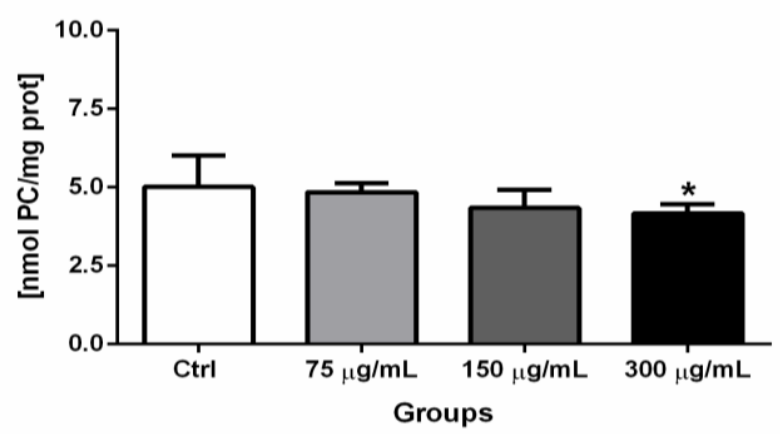

PROTEIN OXIDATION 24h

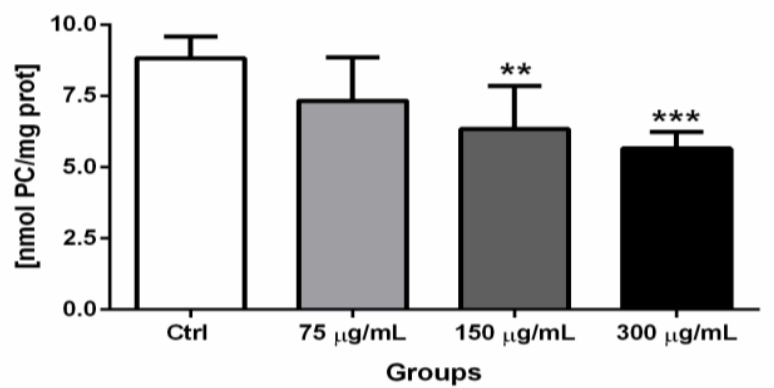

Figure 4 The effect of various concentrations of the Euroean raspberry extract on the protein oxidation of bovine spermatozoa at $0 \mathrm{~h}, 2 \mathrm{~h}$ and $24 \mathrm{~h}$. Each bar represents mean $( \pm \mathrm{SEM})$. The level of significance was set at $* \mathrm{P}<0.05 ; * * \mathrm{P}<$ $0.01, * * * \mathrm{P}<0.001$.

Male reproductive cells have high levels of polyunsaturated fatty acids in their plasma membrane, which are uncovered to oxidative attacks. Our first measurements at $0 \mathrm{~h}$ did not indicate any change after raspberry extract addition. After $2 \mathrm{~h}$ of incubation, the all observed groups showed statistically significant $(\mathrm{P}<0.05)$ effect of European raspberry extract by decreasing levels of lipid peroxidation. The lowest concetration

$(75 \mu \mathrm{g} / \mathrm{mL})$ suggested significantly decreasing lipid damage $(\mathrm{P}<0.05)$, similarly, the other doses, $150 \mu \mathrm{g} / \mathrm{mL}$ and $300 \mu \mathrm{g} / \mathrm{mL}$ showed a significant decrease of lipid peroxidation after $24 \mathrm{~h}$ of in vitro culture. Addition of this substance can be able to protect bovine germ cells before oxidative damages of lipids (Figure 5). 


\section{LIPID PEROXIDATION Oh}

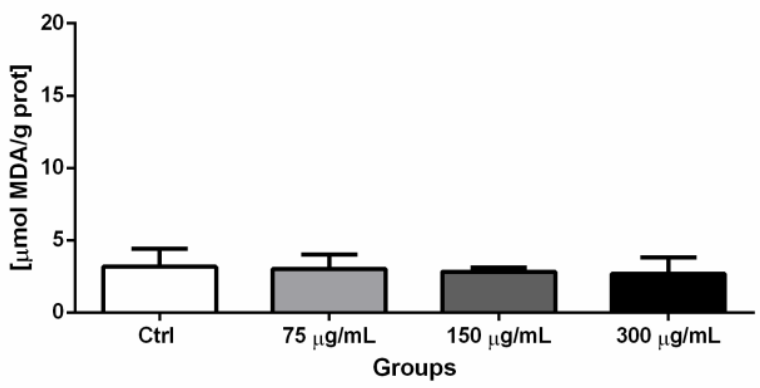

LIPID PEROXIDATION 2h

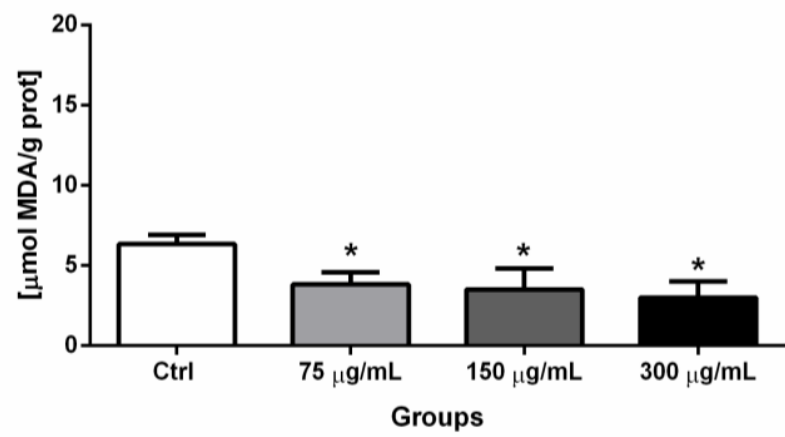

LIPID PEROXIDATION 24h

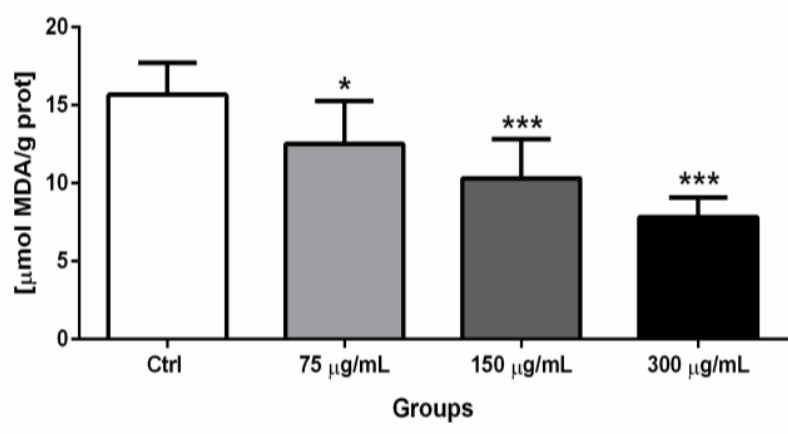

Figure 5 The effect of various concentrations of the Euroean raspberry extract on the lipid peroxidation of bovine spermatozoa at $0 \mathrm{~h}, 2 \mathrm{~h}$ and $24 \mathrm{~h}$. Each bar represents mean $( \pm \mathrm{SEM})$. The level of significance was set at $* \mathrm{P}<0.05 ; * * * \mathrm{P}$ $<0.001$.

Yoon et al. (2011) determined that after in vivo raspberry administration extract to 8 - week old male Wistar rats, this extract intesively increased the weight of the rat testes, epididymal sperm count, sperm motion, and testosterone level compared to the control group. Their results implyed, that raspberry extract has a protective effect to spermatogonial cells against spermatogenic effect and oxidative stress on male reproductive system what is corresponding with our data.

The positive effect of raspberries were verifyed by Jeon $\boldsymbol{e t}$ al. (2008). They investigated the effects of fermentation filtrates from Rubus coreanus on the selected functions of the male reproductive system. They found, that addition of this substance relatively increase the function of the male reproductive sytem by triggering penile erection, improving testosterone levels in serum and enhancing epididymal sperm counts.

The addition of Rubus coreanus leaf and stem extract can help to increase sperm viability and motility during boar semen preservation (Yi et al., 2017).

Noratto et al. (2016) investigated the effects of red raspberry consumption on obese diabetic mice. They detected, that red raspberry consumption can decrease the oxidative and inflammatory stress levels. Similarly, our results showed oxidative termination by significantly decreasing reactive oxygen species, protein oxidation and lipid peroxidation levels. Noratto et al. (2017) demonstrated, that in vivo intake of red raspberry by mice for 8 weeks, showed a protective effect against diabetes-induced oxidative stress.

Another protective effects of raspberry was followed by Garcia $\boldsymbol{e t}$ al. (2017) These authors claimed, that raspberry polyphenols can figure as a dietary route to the retardation or amelioration neurodegenerative - related dysfunctions.

Zhang et al. (2011) reported, that orraly administered Rubus idaeus L. fruits to the experimental rats showed diuretic effect, what means, that raspberry fruits might have protetctive effect against renal diseases.
Ellagic acid is one of the major chemical compound of European raspberry. Ceribasi $\boldsymbol{e t}$ al. (2012) demonstrated the effect of ellagic acid on adriamycin induced testicular and spermatozoal toxicity associated with the oxidative stress in male rats. After 8 weeks of intraperitoneal treated period they found, that ellagic acis has a protective effect on adriamycin induced testicular lipid peroxidation and apoptosis.

\section{CONCLUSION}

This study was aimed to investigate the chemical composition of the Rubus iadeus extract and its in vitro effects on male reproductive cells. The following markers of the bovine spermatozoa were monitored: motility, mitochondrial activity, quantification of ROS as a marker of oxidative stress, protein oxidation and lipid peroxidation. To describe main chemical components of the European raspberry extract the HPLC method was applied. After measuring of the selected paramethers, it can be concluded, that the highest applied concetration of Rubus idaeus extract $(300 \mu \mathrm{g} / \mathrm{mL})$ significantly increased the motility, mitochondrial activity as well as decreased the ROS production, protein oxidation and lipid peroxidation at $2 \mathrm{~h}$ and $24 \mathrm{~h}$. The other two lower doses exhibited positive effects too. Lipid peroxidation was significantly decreased by the lower doses after $2 \mathrm{~h}$ and $24 \mathrm{~h}$. At $24 \mathrm{~h}$, the motility $(75 \mu \mathrm{g} / \mathrm{mL} ; 150 \mu \mathrm{g} / \mathrm{mL})$, mitochondrial activity were significantly increased and the ROS production and protein oxidation were decreased after the additon of $150 \mu \mathrm{g} / \mathrm{mL}$ extract. We can conclude, that European raspberry extract addition in different concetrations caused a significant increase of the sellected parameters, which finally points to the positive and protective effect of this extract on the bovine reproductive cells. At the same time, further data validation for more complex sperm analyses and in vivo experiments are highly recommended.

Acknowledgments: This study was supported by the European Community Project no. 26220220180: Building Research Centre "AgroBioTech", by the VEGA Project no. 1/0039/16, and by the Slovak Research and Development Agency Grant no. APVV-15-0544. Experiments of this study were performed with support of the "CeRA" Team of Excellence.

\section{REFERENCES}

Baby, B., Anthony, P., Vijayan, R. 2017. Antioxidant and anticancer properties of berries. Food Science and Nutrition. http://dx.doi.org/10.1080/10408398.2017.1329198

Bajčan, D., Vollmannová, A., Šimanský, V., Bystrická, J., Trebichalský, P., Árvay, J., Czako, P. (2016). Antioxidant activity, phenolic content and colour of the Slovak cabernet sauvignon wines. Potravinarstvo, 10(1), 8994.https://doi.org/10.5219/534

Baranowska, M. K., Glod, D., Kula, M., Majdan, M., Halasa, R., Matkowski, A., Kozlowska, W., Kawiak, A. 2017. Chemcal composition and biological activity of Rubus idaeus shoots - a traditional herbal remedy of Eastern Europe. BMC Complementary and Alternative Medicine, 14.

Bobinaité, R., Viškelis, P., Venskutonis, P. R. 2012. Variation of total phenolics, anthocyanins, ellagic acid and radical scavening in various raspberry (Rubus spp.) cultivars. Food Chemistry, 132(3), 1495 - 1501. https://doi.org/10.1016/j.foodchem.2011.11.137

Bowen-Frobes, C. S., Zhang, Y., Nair, M. G. 2010. Anthocyanin content, antioxidant, antiinflamatory and anticancer properties of blackberry and raspberry fruits. Journal of Food Composition and Analysis, 23(6), 554-560. https://doi.org/10.1016/j.jfca.2009.08.012

Ceribasi, A. O., Sakin, F., Turk, G., Sonmez, M., Attessahin, A. 2012. Imact of ellagic acid on adrimycin - induced testicular histopathological lessions, apoptosis, lipid peroxidation and sperm damages. Experimental andToxicologic Pathology, 64 (7-8), 717-724. https://doi.org/10.1016/j.etp.2011.01.006

Garcia, G., Nanni, S., Figueira, I., Ivanov, Ines., McDougall, G. J., Stewart, D., Ferreira, R. B., Pinto, P., Silva, R. F. M., Brites, D., Santos, C. N. 2017. Bioaccessible (poly)phenol metabolites from raspberry protect neural cells from oxidative stress and attenuate microglia activation. Food Chemistry, 215, 274 283. https://doi.org/10.1016/j.foodchem.2016.07.128

Gordon, S. C., Woodford, J. A. T. 2000. Aims and objectives of Reduced Applications of Chemicals in European Raspberry Production (RACER) project. Integrated Production of Soft Fruits, 23 (11), 73-79.

Jeon, J. H., Shin, S., Park, D., Jang, J. Y., Choi, B., Kang, J. K., Joo, S. S., Hwang, S. Y., Kim, J. C., Kim, B. Y., Kim, M. R., Kim, Y. B. 2008 Fermentation Filtrates of Rubus corneanus Relax the Corpus Cavernosum and Increase Sperm Count and Motility. Journal of Medicinal Food, 11 (3). https://doi.org/10.1089/jmf.2007.0070

Kashou, A. H., Sharma, R., Agarwal, A. 2013. Assessment of oxidative stress in sperm and semen. Spermatogenesis, 927, 351-361. https://doi.org/10.1007/978-162703-038-0_30

Knazicka, Z., Tvrda, E., Bardos, L. \& Lukac, N. (2012). Dose- and timedependent effect of copper ions on the viability of bull spermatozoa in different media. Journal of Environmental Science and Health, Part A, 47(9), 1294-1300. https://doi.org/10.1080/10934529.2012.672135 
Luksic, L., Árvay, J., Vollmannova, A., Toth, T., Skrabanja, V., Trcek, J., Germ, M. \& Kreft, I. (2016). Hydrothermal treatment of Tartary buckwheat grain hinders the transformation of rutin to quercetin. Journal of Cereal Science, 72, 131-134. https://doi.org/10.1016/j.jcs.2016.10.009

Noratto, G., Chew, B. P., Ivanov, I. 2016. Red raspberry decreases heart biomarkers of cardiac remodeling associated with oxidative and inflamatory stress in obese diabetic bd/db mice. Food \& Function, 7, 4944-4955. https://doi.org/10.1039/C6FO01330A

Noratto, G. D., Chew, B. P., Atienza, L. M. 2017. Red raspberry (Rubus iadeus L.) intake decreases oxidative stress in obese diabetic $(\mathrm{db} / \mathrm{db})$ mice. Food Chemistry, 225, 305-314. https://doi.org/10.1016/j.foodchem.2017.01.097

Ponder, A., Hallmann, E. 2019. The effects of organic and conventional farm managment and harvest time on the polyphenol content in different raspberry cultivars. Food Chemistry, 301. https://doi.org/10.1016/j.foodchem.2019.125295

Rao, A. V., Snyder, D. M. 2010. Raspberries and Human Health: A Review. Journal of Agricultural an Food Chemistry, 58 (7), 3871 - 3883 https://doi.org/10.1021/jf903484g

Teng, H., Fang, T., Lin, Q., Song, H., Liu, B., Chen, L. 2017. Red raspberry and its anthocyanins: Bioactivity beyond antioxidant capacity. Triends in Food Science \& Technology, 66, 153-165. http://dx.doi.org/10.1016/j.tifs.2017.05.015

Tvrda E, Kovacik A, Tusimova E, Paal D, Mackovich A, Alimov J, Lukac N (2016): Antioxidant efficiency of lycopene on oxidative stress - induced damage in bovine spermatozoa. Journal of Animal Science and Biotechnology 7, 5063. https://doi.org/10.1186/s40104-016-0113-9

Tvrdá, E., Konečná, N., Zbyňovská, K. \& Lukáč, N. (2018). Antioxidant Effects of Peppermint (Mentha piperita) Extract on the Oxidative Balance of Rabbit Spermatozoa. Journal of Advanced Agricultural Technologies, 5(2), 117-122. http://dx.doi.org/10.18178/joaat.5.2.117-122

Veljković, B., Dordević, N., Dolićanin, Z., Ličina, B., Topuzović, M., Stanković, M., Zlatić, N. 2019. Antioxidant and Anticancer Properties of Leaf and Fruit Extracts of the Wild Raspberry (Rubus iadeus L.). Not Bot Horti Agrobo, 47 (2), 359 - 367. https://doi.org/47.15835/nbha47111274

Vera, J. R., Patel, A. V., Dacke, Ch. G. 2002. Relaxant activity of raspberry (Rubus idaeus) leaf extract in guinea-pig ileum in vitro. Phytotherapy Research, 16(7), 665-668. https://doi.org/10.1002/ptr.1040

Weber, D., Davies, M. J., Grune, T. 2015. Determination of protein carbonyls in plasma, cell extracts, tissue homogenates, isolated proteins: Focus on sample preparation and derivatization conditions. Redox Biology, 5, 367-380. https://doi.org/10.1016/j.redox.2015.06.005

Yi, Y. J., Cho, M., Heo, J. M., Lee, S. M. 2017. Effect of Rubus coreanus leaf and stem extract on boar spermatozoa. Journal of Biomedical and Translational Research, 18 (2).

Yoon, J., Kim, W. N., Kim, S. W., Kim, J. S., Kim, H. Y., Choi, B. J., Chang, M. S., Park, K. S. 2011. Anti - Oxidative, Spermatogenic Effects of Raspberry on GC - 1 Spermatogonial Cells and Rat Testes. Biology of Reproduction, 85 (1), 558. https://doi.org/10.1093/biolreprod/85.s1.558

Zhang, Y., Zhang, Z., Yang, Y., Zu, X., Guan, D. I., Guan, Y. 2011. Diuretic Activity of Rubus idaeus L (Rosaceae) in Rats. Tropical Journal of Pharmaceutical Research, 10(3). http://dx.doi.org/10.4314/tjpr.v10i3.15 